\title{
A Study on the Effect of Alfalfa in Sheep Rations on Feeding Efficiency and Reproductive Performance
}

\author{
Al-Geldawy ${ }^{1}$ A. R.; A. A. Osman ${ }^{2}$; M. M. Awad ${ }^{2}$ and M. F. El-Sayes ${ }^{3}$ \\ ${ }^{1}$ Improved Agricultural Systems Project, Ismailia, Agricultural Research Centre, Egypt. \\ ${ }^{2}$ Department of Animal Production, Faculty of Agriculture, Suez Canal University, Egypt. \\ ${ }^{3}$ Animal Production Research Institute, Agriculture Research Center, Egypt.
}

\section{Received: $1 / 1 / 2014$}

\begin{abstract}
The objectives of the present study were to investigate the effects of alfalfa forage in ewes' rations on feeding and reproductive performance. Three experiments were carried out in this study during 10 months, the first experiment was carried out on 51 local ewes in 3 groups (17 in each) and the second experiment was carried out on 9 ewes ( 3 in each), while the third experiment was conducted on a mature fistulated Buffalo bull. The rations provided to animals were classified into three experimental rations. The first ration (control) was made up of $82 \%$ concentrate feed mixture (CFM) and 18\% wheat straw, the second ration consisted of 50\% CFM, 30\% fresh alfalfa and $20 \%$ maize grains and The third ration composed of $60 \%$ fresh alfalfa and $40 \%$ maize grains, on DM basis. The rations were offered to ewes in quantities to meet the nutrient requirements according to NRC (1985). Animals in exp. 1 and 2 were randomly allotted into three treatment groups, the 1st group was control which consumed the 1st ration, treatment 1(T1) which consumed the 2nd ration and treatment 2(T2) which consumed the 3rd ration. Results revealed that a significantly increase $(\mathrm{p} \leq 0.05)$ in a crude protein disappearance of alfalfa than concentrate feed mixture or maize grains was observed at $4 \mathrm{hrs}$. post-incubation. Control group which was fed on CFM and wheat straw had a significantly increase $(\mathrm{p} \leq 0.05)$ in conception rate and lambing rates than other groups (T1 and T2 which were fed on rations contained alfalfa). On the other hand, T2 had the significantly higher concentration $(\mathrm{p} \leq 0.05)$ of Progesterone than $\mathrm{T} 1$ and control at the $3 \mathrm{rd}$ day before estrus day. This study showed that the use of alfalfa caused reduction in reproductive efficiency of ewes and recommended the maximum safe adding of fresh green alfalfa on the dry matter basis in the diets of ewes should not to exceed $30 \%$ of the total nutrient requirements.
\end{abstract}

Keywords: Alfalfa, Phytoestrogen, Conception rate, Lambing rate, Sheep, Sex hormone, Feed efficiency.

\section{INTRODUCTION}

Alfalfa is grown mainly on newly reclaimed lands as green forage for livestock. Eight to ten cuts per year could be obtained (Rammah et al., 1995). Alfalfa is the main green forage in Ismailia Governorate for feeding ruminants.

Legumes as Alfalfa diets for ruminants contains high CP and low energy (EL-Sayes and Gaafer, 1998, Abdel-Malik et al., 2001, Soliman et al., 2005 and Turner et al., 2011). Gabra (1984) confirmed that alfalfa forage is not adequate to fulfill animal requirements for high production. Strategic energy supplementation is usually done to increase digestible energy intake to improve performance of small ruminants (EL-Sayes and Gaafer, 1998, Soliman et al., 2005 and Turner et al., 2011).

Protein value of alfalfa might be reduced by nitrogen losses that occur during extensive rumen degradation (Broderick, 1995; Dhiman and Satter, 1997; Elizalde et al., 1999a; Gonzalez et al., 2001; Broderick, 2006; Pozdišek and Vaculova, 2008).

Alfalfa potentially contains phytoestrogens which can reduce the reproductive efficiency of domestic ruminants (Bennets, 1946, Lightfoot and Wroth, 1974, Romero et al., 1997 and Clinton, 2002).

\section{MATERIALS AND METHODS}

This study was conducted at the farm of Animal Production Station of Improved Agricultural Systems Project (Suez Canal East, Ismailia Governorate, Agricultural Research Center, Egypt). Alfalfa was cultivated in reclaimed sandy soils at the Suez Canal East (Sinai).

In Situ nylon bag technique was carried out in Ismailia Agricultural Research Station according to Mehrez and Ørskov (1977), where 4gm of dry feed sample (milled through $2 \mathrm{~mm}$ screen) were placed in each nylon bag prepared from polyester cloth $(41 \mu \mathrm{m}$ pore size). The nylon bags were incubated for 4,8 and 12 hours in rumen of buffalo bull. The In Situ dry matter disappearance (ISDMD), In Situ crude protein disappearance (ISCPD) and In Situ crude fiber disappearance (ISCFD) of feed samples were determined.

51 local ewes in 3 groups (17 in each) were used to study their reproductive performance and lambing production. 9 ewes from the experimental groups (3 in each) randomly selected after ewes parturition and weaning their lambs to study the effect of feeding alfalfa on the level of the progesterone hormone around estrus day.

The rations provided to animals are classified into three experimental rations, the first ration (control) was made up of $82 \%$ concentrate feed mixture (CFM) which was consist of $60 \%$ corn, $24 \%$ wheat bran $13 \%$ Soybean meal $3 \%$ feed additives, plus $18 \%$ wheat straw, the second ration (T1) consisted of 50\% CFM, 30\% fresh alfalfa and $20 \%$ maize grains and the third ration (T2) composed of $60 \%$ fresh alfalfa and $40 \%$ maize grains, on DM basis. The rations were calculated to meet the nutrient requirements according to NRC (1985).

Alfalfa was cutting then offered with dietary rations twice daily at 7 AM and 3 PM. Animal had access to water at all times. 
Chemical analysis of ingredients and rations were determined according to the methods of A.O.A.C. (1990).

The serum progesterone level was measured by using ELISA technique according to DIA METRA for routine analysis of $17 \mathrm{OH}$ Progesterone (Direct immunoenzymatic determination of $17 \mathrm{OH}$ Progesterone in human serum or plasma).

All data were subjected to analysis of variance and least squares analysis was performed using the General Linear Models (GLM) procedure of the SAS statistical package (SAS, 1999). Mean differences were compared using Duncan' multiple range test (Duncan, 1955). Data were analyzed using the following model:

$$
\begin{aligned}
& \mathrm{Yi}=\mu+\mathrm{Ti}+\mathrm{ei} \\
& \text { Where } \\
& \mathrm{Yi}=\text { Individual observation. } \\
& \mu \quad=\text { the overall mean for the trait under consideration } \\
& \mathrm{Ti}=\text { the effect of the treatment } \\
& \mathrm{ei}=\text { random residual error }
\end{aligned}
$$

\section{RESULTS AND DISCUSSION}

\section{Chemical composition of ingredients and experimental rations:}

Table (1) showed the average percentage composition of ingredients and rations of experiments. The chemical composition of ingredients showed that the crude protein (CP) content of alfalfa was very high compared with maize grains. The nitrogen free extract content (NFE) was low in alfalfa compared with maize grains. Wheat straw had a low protein and NFE and high CF. The values of chemical composition in this work are in general within the range of values obtained by Medina et al. (1972); Manget Ram and Mundgal (1997); Bo Gohl (1981); Chauhan et al. (1987); Gabra et al. (1992); Abd-El-Halim et al. (1992), Rammah et al. (1995) and EL-Sayes and Gaafer, (1998). In addition, the chemical composition of experimental rations showed an equal nearly values of NFE.

Table (1): Chemical composition of ingredients and rations of experiments.

\begin{tabular}{ccccccccc}
\hline Items & & DM\% & OM\% & CP\% & CF\% & EE\% & NFE\% & ASH\% \\
\hline Ingredients & & & & & & & \\
\hline $\begin{array}{c}\text { Concentrate feed } \\
\text { mixture }\end{array}$ & as fed & 88.8 & 77.6 & 14.0 & 6.5 & 2.6 & 54.5 & 11.2 \\
Maize grains & DM basis & 100 & 87.3 & 15.8 & 7.3 & 2.9 & 61.3 & 12.7 \\
& as fed & 88.5 & 86.2 & 9.1 & 1.9 & 3.9 & 71.3 & 2.3 \\
Alfalfa & DM basis & 100 & 97.4 & 10.3 & 2.1 & 4.4 & 80.6 & 2.6 \\
& as fed & 20.4 & 18.0 & 5.7 & 4.0 & 0.6 & 7.7 & 2.4 \\
Wheat straw & DM basis & 100 & 88.4 & 28.2 & 19.6 & 2.9 & 37.7 & 11.6 \\
& as fed & 92.0 & 79.9 & 4.7 & 31.1 & 1.2 & 42.8 & 12.1 \\
\hline Rations & DM basis & 100 & 86.9 & 5.1 & 33.9 & 1.3 & 46.6 & 13.1 \\
\hline Control & as fed & 89.8 & 79.81 & 11.98 & 10.66 & 2.45 & 54.72 & 10.03 \\
& DM basis & 100 & 88.84 & 13.33 & 11.87 & 2.72 & 60.91 & 11.16 \\
Treatment 1 & as fed & 89.9 & 81.72 & 17.41 & 9.40 & 2.87 & 52.03 & 8.22 \\
& DM basis & 100 & 90.86 & 19.36 & 10.46 & 3.19 & 57.86 & 9.14 \\
Treatment 2 & as fed & 91.4 & 84.35 & 19.84 & 12.68 & 2.94 & 48.90 & 7.03 \\
& DM basis & 100 & 92.31 & 21.71 & 13.87 & 3.22 & 53.51 & 7.69 \\
\hline
\end{tabular}

"A concentrate feed mixture (CFM) was formulated from maize grains, 60\%; wheat bran, 24\%; soy bean meal, $13 \%$ and $3 \%$ mineral mix.

\section{In Situ dry matter disappearance (ISDMD), In Situ crude protein disappearance (ISCPD) and In Situ crude fiber disappearance (ISCFD) of ingredients and different experimental rations:}

The dry matter disappearance of alfalfa was nearly similar with concentrate feed mixture with insignificant disappearance at all incubation periods, while dry matter disappearance of wheat straw was significantly $(p \leq 0.05)$ lower than other ingredients at all incubation periods, however the dry matter disappearance of maize grains was intermediate between alfalfa and concentrate feed mixture with insignificant disappearance at $8 \mathrm{hrs}$. postincubation and it was significantly $(\mathrm{p} \leq 0.05)$ higher than others at $12 \mathrm{hrs}$. post-incubation (Table 2). On the other hand, the dry matter disappearance of control was significantly $(\mathrm{p} \leq 0.05)$ higher at 4 and $8 \mathrm{hrs}$. and significantly $(p \leq 0.05)$ lower at 12 hrs. post-incubation than rations contained alfalfa (T1 and $\mathrm{T} 2$ ) as shown in Table 2. Similar results were showed by de Boer et al. (1987) and Mehrez et al. (2001).

The crude protein disappearance of alfalfa was significantly $(p \leq 0.05)$ higher than concentrate feed mixture or maize grains at $4 \mathrm{hrs}$. post-incubation and consequently control rations was significantly $(\mathrm{p} \leq 0.05)$ lower than T2 and insignificantly lower than T1 at 4 hrs. post-incubation (Table 2). This result is lie within the data obtained by Mathers et al. (1977), Crawford et al. (1978), de Boer et al. (1987) and Mehrez et al. (2001).

The crude fiber disappearance of all ingredients was nearly and without any significant $(\mathrm{p} \leq 0.05)$ 
disappearance at 4 and $8 \mathrm{hrs}$. post-incubation. $(\mathrm{p} \leq 0.05)$ higher than wheat straw at 12 hrs. postincubation. On the other side, the crude fiber disappearance of control ration was significantly $(\mathrm{p} \leq 0.05)$ lower at $8 \mathrm{hrs}$. and insignificantly lower at 12 hrs. post-incubation than rations contained alfalfa (T1 and T2) as shown in Table 2. The values of control rations were less than of Mehrez et al. (2001).

\section{Reproductive performance of ewes fed alfalfa:}

Reproductive performances of ewes are presented in Table 7. The data showed that considerable variations $(\mathrm{P} \leq 0.05)$ were observed among percentages of conception rate and lambing rate and they were recorded $60,36.4$ and $18.2 \%$ conception rate and 60 ,
Concentrate feed mixture and alfalfa were significantly 36.4 and $15.9 \%$ lambing rate in groups of control (fed on concentrate feed mixture and wheat straw), T1 (fed on $30 \%$ alfalfa) and $\mathrm{T} 2$ (fed on alfalfa ration), respectively. The $\mathrm{T} 2$ group which was fed on alfalfa ration had a very low conception rate and lambing rates than T1 group which was fed on $30 \%$ alfalfa and control group which was fed on CFM and wheat straw. It has also been demonstrated by Bennets (1946); Lightfoot and Wroth (1974); Romero et al. (1997) and Clinton (2002) that Alfalfa potentially contains phytoestrogens. They reported that phytoestrogens can reduce the reproductive efficiency of domestic ruminants. While, twining rate $\%$, weaning rate $\%$ and ewes efficiency were insignificantly affected.

Table (2): In Situ DM, CP and CF disappearance of alfalfa and other ingredients utilized in ewes' rations and the different experimental rations.

\begin{tabular}{|c|c|c|c|c|c|c|c|c|c|}
\hline \multirow{3}{*}{ Item } & \multirow{2}{*}{\multicolumn{3}{|c|}{$\begin{array}{c}\text { DM disappearance (\%) } \\
\begin{array}{c}\text { Incubation period } \\
\text { (hour) }\end{array}\end{array}$}} & \multirow{2}{*}{\multicolumn{3}{|c|}{$\begin{array}{c}\text { CP disappearance (\%) } \\
\begin{array}{c}\text { Incubation period } \\
\text { (hour) }\end{array}\end{array}$}} & \multirow{2}{*}{\multicolumn{3}{|c|}{$\begin{array}{c}\text { CF disappearance (\%) } \\
\begin{array}{c}\text { Incubation period } \\
\text { (hour) }\end{array} \\
\end{array}$}} \\
\hline & & & & & & & & & \\
\hline & 4 & 8 & 12 & 4 & 8 & 12 & 4 & 8 & 12 \\
\hline \multicolumn{10}{|l|}{ Ingredients } \\
\hline Dried alfalfa & $26.2^{\mathrm{ab}}$ & $34.7^{\mathrm{a}}$ & $26.2^{\mathrm{ab}}$ & $40.2^{\mathrm{a}}$ & $43.9^{\mathrm{a}}$ & $43.9^{\mathrm{a}}$ & $2.2^{\mathrm{a}}$ & $6.5^{\mathrm{a}}$ & $13.9^{\mathrm{a}}$ \\
\hline Wheat Straw & $11.8^{\mathrm{c}}$ & $13.4^{\mathrm{b}}$ & $11.8^{\mathrm{c}}$ & $3.7^{\mathrm{b}}$ & $4.7^{\mathrm{c}}$ & $9.8^{\mathrm{c}}$ & $3.0^{\mathrm{a}}$ & $3.2^{\mathrm{a}}$ & $7.7^{\mathrm{b}}$ \\
\hline Maize grains & $22.3^{b}$ & $34.5^{\mathrm{a}}$ & $22.3^{\mathrm{b}}$ & $30.6^{\mathrm{b}}$ & $32.1^{\mathrm{b}}$ & $35.8^{b}$ & $5.1^{\mathrm{a}}$ & $5.8^{\mathrm{a}}$ & $11.2^{\mathrm{ab}}$ \\
\hline $\begin{array}{l}\text { Concentrate feed } \\
\text { mixture }\end{array}$ & $29.5^{\mathrm{a}}$ & $35.4^{\mathrm{a}}$ & $29.5^{\mathrm{a}}$ & $32.8^{\mathrm{ab}}$ & $45.5^{\mathrm{a}}$ & $47.2^{\mathrm{a}}$ & $1.9^{\mathrm{a}}$ & $2.0^{\mathrm{a}}$ & $13.8^{\mathrm{a}}$ \\
\hline \multicolumn{10}{|l|}{ Rations } \\
\hline Control & $32.2^{\mathrm{a}}$ & $32.9^{a}$ & $33.2^{\mathrm{c}}$ & $32.4^{\mathrm{b}}$ & $37.8^{a}$ & $38.3^{\mathrm{b}}$ & $1.5^{\mathrm{a}}$ & $2.0^{\mathrm{b}}$ & $7.2^{\mathrm{a}}$ \\
\hline Treatment 1 & $23.4^{\mathrm{b}}$ & $29.4^{\mathrm{c}}$ & $36.9^{\mathrm{b}}$ & $35.2^{\mathrm{ab}}$ & $37.2^{\mathrm{a}}$ & $43.7^{b}$ & $5.0^{\mathrm{a}}$ & $5.5^{\mathrm{a}}$ & $8.8^{\mathrm{a}}$ \\
\hline Treatment 2 & $25.3^{b}$ & $30.2^{\mathrm{b}}$ & $45.7^{\mathrm{a}}$ & $39.3^{\mathrm{a}}$ & $39.6^{\mathrm{a}}$ & $52.9^{\mathrm{a}}$ & $3.9^{\mathrm{a}}$ & $5.4^{\mathrm{a}}$ & $10.8^{\mathrm{a}}$ \\
\hline
\end{tabular}

${ }^{a b c}$ means in the same columns with different superscripts are significantly $(\mathrm{p} \leq 0.05)$ differed.

Table (3): Reproductive performance of ewes fed alfalfa.

\begin{tabular}{|c|c|c|c|c|c|c|c|c|c|}
\hline \multirow{3}{*}{ Item } & \multirow{2}{*}{\multicolumn{3}{|c|}{$\begin{array}{c}\text { Control } \\
\text { Insemination }\end{array}$}} & \multirow{2}{*}{\multicolumn{3}{|c|}{$\begin{array}{c}\text { Treatment } 1 \\
\text { Insemination }\end{array}$}} & \multirow{2}{*}{\multicolumn{3}{|c|}{$\begin{array}{c}\text { Treatment } 2 \\
\text { Insemination }\end{array}$}} \\
\hline & & & & & & & & & \\
\hline & 1st & 2nd & 3d & 1 st & $2^{\text {nd }}$ & 3d & $1 \mathrm{st}$ & $2^{\text {nd }}$ & 3d \\
\hline Number of ewes inseminated & 17 & 5 & 3 & 17 & 9 & 7 & 17 & 15 & 12 \\
\hline Number of ewes conceived & 12 & 2 & 1 & 8 & 2 & 2 & 2 & 3 & 3 \\
\hline Conception rate\% (CR\%) & 70.6 & 40 & 33.3 & 47.1 & 22.2 & 28.6 & 11.8 & 20 & 25 \\
\hline Overall means CR\% & \multicolumn{3}{|c|}{$60.0 \pm 2.3 a$} & \multicolumn{3}{|c|}{$36.4 \pm 1.4 \mathrm{~b}$} & \multicolumn{3}{|c|}{$18.2 \pm 1.5 \mathrm{c}$} \\
\hline Number of ewes parturited & 12 & 2 & 1 & 8 & 2 & 2 & 1 & 3 & 3 \\
\hline Lambing rate\% (LR\%) & 70.6 & 40 & 33.3 & 47.1 & 22.2 & 28.6 & 5.9 & 20 & 25 \\
\hline Overall means LR\% & \multicolumn{3}{|c|}{$60.0 \pm 2.3 a$} & \multicolumn{3}{|c|}{$36.4 \pm 1.4 \mathrm{~b}$} & \multicolumn{3}{|c|}{$15.9 \pm 1.1 \mathrm{c}$} \\
\hline Number of lambs were born & 17 & 3 & 1 & 12 & 4 & 3 & 2 & 4 & 3 \\
\hline Twining rate\% (TR\%) & 141.7 & 150 & 100 & 150 & 200 & 150 & 200 & 133.3 & 100 \\
\hline Overall means TR\% & \multicolumn{3}{|c|}{$140.0 \pm 3.7 a$} & \multicolumn{3}{|c|}{$158.3 \pm 2.2 \mathrm{a}$} & \multicolumn{3}{|c|}{$128.6 \pm 2.5 \mathrm{a}$} \\
\hline Number of lambs were weaned & 11 & 2 & 1 & 7 & 2 & 0 & 2 & 1 & 3 \\
\hline Weaning rate\% (WR\%) & 91.7 & 100 & 100 & 87.5 & 100 & 0 & 200 & 33.3 & 100 \\
\hline Overall means WR\% & \multicolumn{3}{|c|}{$93.3 \pm 3.3 \mathrm{a}$} & \multicolumn{3}{|c|}{$75.0 \pm 2.7 a$} & \multicolumn{3}{|c|}{$85.7 \pm 2.9 a$} \\
\hline Overall weight of lambs weaned (kg) & 217.6 & 55.9 & 0 & 171 & 28.8 & 0 & 35.6 & 23.4 & 61.5 \\
\hline ewes efficiency $\mathrm{EE} \mathrm{Kg/ewe}$ & 18.1 & 28 & 0 & 21.3 & 14.4 & 0 & 35.6 & 7.8 & 20.5 \\
\hline Overall means EE (kg/ewe) & \multicolumn{3}{|c|}{$18.2 \pm 1.6 \mathrm{a}$} & \multicolumn{3}{|c|}{$16.6 \pm 1.4 a$} & \multicolumn{3}{|c|}{$17.2 \pm 1.8 \mathrm{a}$} \\
\hline
\end{tabular}

abc means in the same row with different superscripts differ significantly $(\mathrm{P} \leq 0.05)$. 
Table (4): Performance of lambs produced by ewes fed alfalfa.

\begin{tabular}{lccc}
\hline \multicolumn{1}{c}{ Item } & Control & Treatment 1 & Treatment 2 \\
\hline Number of Lambs born & 21 & 19 & 9 \\
Average of born weight kg & 3.86 & 3.57 & 3.79 \\
Average of weaning weight kg & 19.53 & 22.14 & 20.07 \\
Number of Lambs weaned & 14 & 9 & 6 \\
Mortality (\%) & 33.3 & 52.6 & 33.3 \\
Growth rate (gm./day) & 173 & 200 & 180 \\
\hline
\end{tabular}

Table (5): Progesterone hormone level in serum of ewes fed alfalfa.

\begin{tabular}{cccc}
\hline \multirow{2}{*}{ Estrus days } & \multicolumn{2}{c}{ Progesterone Concentration } & (ng/ ml) \\
\cline { 2 - 4 } & Control & T1 & $1.63^{\mathrm{a}}$ \\
\hline $\mathbf{- 6}$ & $0.507^{\mathrm{a}}$ & $1.298^{\mathrm{a}}$ & $1.48^{\mathrm{a}}$ \\
$\mathbf{- 5}$ & $0.734^{\mathrm{a}}$ & $1.686^{\mathrm{a}}$ & $2.48^{\mathrm{a}}$ \\
$\mathbf{- 4}$ & $0.503^{\mathrm{a}}$ & $0.665^{\mathrm{a}}$ & $\mathbf{2 . 2 1}^{\mathrm{a}}$ \\
$\mathbf{- 3}$ & $\mathbf{0 . 4 3 9 ^ { \mathrm { b } }}$ & $\mathbf{0 . 3 7 5 ^ { \mathrm { b } }}$ & $0.84^{\mathrm{a}}$ \\
$\mathbf{- 2}$ & $0.573^{\mathrm{a}}$ & $1.32^{\mathrm{a}}$ & $0.175^{\mathrm{a}}$ \\
$\mathbf{- 1}$ & $0.166^{\mathrm{a}}$ & $0.256^{\mathrm{a}}$ & $0.222^{\mathrm{a}}$ \\
$\mathbf{0}$ & $0.140^{\mathrm{a}}$ & $0.152^{\mathrm{a}}$ & $0.090^{\mathrm{a}}$ \\
$\mathbf{1}$ & $0.077^{\mathrm{a}}$ & $0.245^{\mathrm{a}}$ & $0.117^{\mathrm{a}}$ \\
$\mathbf{2}$ & $0.164^{\mathrm{a}}$ & $0.336^{\mathrm{a}}$ & $0.100^{\mathrm{a}}$ \\
$\mathbf{3}$ & $0.244^{\mathrm{a}}$ & $0.365^{\mathrm{a}}$ & $0.017^{\mathrm{a}}$ \\
$\mathbf{4}$ & $0.077^{\mathrm{a}}$ & $0.384^{\mathrm{a}}$ & $0.255^{\mathrm{a}}$ \\
$\mathbf{6}$ & $0.407^{\mathrm{a}}$ & $0.495^{\mathrm{a}}$ & $0.420^{\mathrm{a}}$ \\
\hline
\end{tabular}

${ }^{\text {ab }}$ means in the same row with different superscripts differ significantly $(\mathrm{P} \leq 0.05)$.

In the present study, the number of lambs born of control and T1 groups was higher than T2 group and it may be referred to the significantly $(\mathrm{p} \leq 0.05)$ variation of lambing rate among different groups as showed in Table 4. While, born weight, weaning weight and number of lambs weaned were unaffected.

The daily body gain of lambs was increased with 15.6 and $4.04 \%$ than control in T1 and T2, respectively.

\section{Progesterone levels in serum of ewes fed alfalfa:}

Progesterone hormone levels in serum of experimental groups around the estrus day were showed in Table 5. The data showed that considerable variations $(\mathrm{P} \leq 0.05)$ among experimental groups, where $\mathrm{T} 2$ had the highest concentration of Progesterone than the T1 and control groups at the 3rd day before the estrus day, and values recorded $0.439,0.375$ and $2.21 \mathrm{ng} / \mathrm{ml}$ of ewe serum in groups of control, $\mathrm{T} 1$ and $\mathrm{T} 2$, respectively. While, other days were insignificantly affected. This result has been demonstrated by Johnston, (2003) who noticed that Phytoestrogens may affect the bioavailability of sex hormones by binding or stimulating the synthesis of sex hormone binding globulin (SHBG).

\section{CONCLUSION}

It could be concluded that the use of alfalfa as green forage in ewes' nutrition caused reduction in reproductive efficiency and it is recommended that the maximum adding of fresh green alfalfa should not exceed $30 \%$ of the total nutrient requirements on dry matter basis in ewe's rations especially around mating stage.

\section{REFERENCES}

A.O.A.C. (1990). Association of Official Agricultural Chemists. Official Methods of Analysis. 15th Edition. Washington D.C. USA.

Abd El-Halim, A. Z., Hanna, I. A and Mahmoud, T. A (1992). Productivity and forage quality of some Alfalfa cultivars on newly reclaimed sandy soils. Egypt. J. Appl. Sci., 7(9): 407- 427.

Abdel-Malik W. H., M. F. El-Sayes, A. E. M. Khinizy and E. Soliman (2001). Yield and quality of berseem and alfalfa cultivated in newly reclaimed sandy soil in response to foliar trace mineral fertilization and its effect on lamb performance. Egyptian J. Nutrition and Feeds: 167- 177.

Bennetts, H.W., Underwood, E.J., Shier, F.L. (1946). A specific breeding problem of sheep on subterranean clover pastures in Western Australia. Australian Veterinary Journal. 22:2-12.

Bo Gohl (1981). Tropical feeds. FAO Animal production and Health series No. 12 (book).

Broderick G.A. (1995). Desirable characteristics of forage legumes for improving protein utilization in ruminants. Journal of Animal Science, 73, 27602773. 
Broderick G.A. (2006). Improving nitrogen utilization in the rumen of the lactating dairy cow. In: Florida Ruminant Nutrition Symposium, February 1-2, 2006, Best Western Gateway Grand, Gainesville, FL, USA. Available at http://dairy.ifas.ufl.edu/files/rns/2006/Broderick. pdf

Chauhan, T. R., Mehndiratta, P. D and Sidhu, B. S (1987). Chemical composition. In- Vitro dry matter digestibility and nutrient production potential of three improved of Lucerne (Medicago Sativa L.) Indian. J. Dairy Sci. 40, 3.

Clinton Sexson. (2002). Effects of Alfalfa on Uterine Growth of Ovariectomized Preoubertal Ewe Lambs. M.Sc. Thesis, Oregon State University.

Crawford,R. J. Jr., Hoover, w. H., Sniffen 1, C. J. and Crooker, B. A, (1978). Degradation of feedstuff nitrogen in the rumen vs nitrogen solubility in three solvents. Journal of animal science, vol. 46, no. 6 .

De Boer, G., Murphy, J. J. and Kennelly, J. J. (1987). A modified method for determination of In Situ rumen degradation of feedstuffs. Can. J. Anim. Sci. 67:93-102.

Dhiman T.R. and Satter L.D. (1997). Yield response of dairy cows fed different proportions of alfalfa silage and corn silage. Journal of Dairy Science, 80, 2069-2082.

Duncan, D. B. (1955). Multiple range and multiple Ftest. Biometerics, 11: 1-42.

Elizalde J.C., Merchen N.R and Faulkner D.B. (1999a). Supplemental cracked corn for steers fed fresh alfalfa: II. Protein and amino acid digestion. Journal of Animal Science, 77, 467-475.

EL-Sayes, M. F and Gaafer, E. M (1998). Effect of supplementation of alfalfa forage with Maize grains on ration quality and lambs performance. Egyptian. J of Applied Sci. Vol. 13 (4): 1-9.

Gabra, M. A., Moustafa, M. R. M and Khinizy, A. E. M (1992). Nutritional studies on interseeding barly (Hordeum Vulgar L.) with some leguminous winter forage sown on north western coast. J. Agric. Sci. Mansoura Univ. 17 (10): 3132-3139.

Gabra, M.A. (1984). Studies on the productivity and feeding qualities of some annual and perennial forages as affected by some agronomic practices fed to sheep in metabolism trials including nutritional balances. Ph.D. Thesis, Fac. of Agric., Cairo Univ.

Gonzalez J., Faria-Marmol J., Rodriguez C.A and Alvir M. R. (2001): Effect of stage of harvest on the protein value of fresh lucerne for ruminants. Reproduction Nutrition Development, 41, 381392.

Johnston, I. (2003). Phytochem Functional Foods. CRC Press Incorporated. pp. 66-68.

Lightfoot, R. J and Wroth, R. H. (1974). The mechanism of temporary infertility in ewes grazed on oestrogenic subterranean clover prior to and during joining. Proceedings of the Australian Society for Animal Production.10:130-134.

Manget Ram and Mundgal, V. D (1997). Comparative chemical composition In vitro Nutrient digestibility and metabolizable energy of wheat straw, berseem and Lucerne fodders. J. Anim. Sci. 33, (4) 1980.

Mathers, J. C., C. M. Horton and E. L. Miller. (1977). Rate and extent of protein degradation in the rumen. Proc. Nun-. Soc. 36: 37A. (Abstr).

Medina, B. M., Peinado, L. E. and Gomez, C. A. (1972). Comparative experiments on silage effect of the exclusion of air and chopping on the conservation of wilted Lucerne. Archivose de zootecnia, 21 (83): $241-262$.

Mehrez, A. Z. and E. R. Ørskov (1977). A study of the artificial fiber bag technique for determining the digestibility of feeds in the rumen. J. Agric. Sci., Camb., 88: 645.

Mehrez, A. Z., E. M. Soliman, M. Y. El-Ayek, E. A. ElAyouty and M. E. El-Kholany (2001). Influence of roughage to concentrate ratio and type of roughage on digestibility, some rumen parameters and fiber fractions degradability of tested rations with ruminants. Egyptian J. Nutrition and Feeds 4 (Special Issue): 193- 207.

National Research Council, (1985). Nutrient Requirements of Sheep. Washington, USA.

Pozdišek J and Vaculova K. (2008). Study of wheat (Triticum aestivum L.) quality for feeding ruminants using in vitro and in vivo methods. Czech Journal of Animal Science, 53, 253-264.

Rammah, A. M., EL-Nahrawy, M. A., Mousa, M.E and Hanna, I. A (1995). Performance of thirteen Egyption Alfalfa landraces and three local cultivars grown in sandy soil. Egypt. J. Appl. Sci. 10 (12): 318-330.

Romero-R, C.M., Tarragó Castellanos, M.R., Muñoz Mendoza, R., Arista Reyes, R., Rosado García, A. (1997). Síndrome estrogénico en vacas lecheras por consumo de alfalfas con grandes cantidades de coumestrol. Veterinaria México. 28:25-30.

SAS (1999). Statistical Analysis Systems Institute. SAS/STAT user's guide: release 8 SAS institute Inc., Cary, NC. USA.

Soliman E. S, A. M. Aiad and A. A. Zaki (2005). Utilization of cassava instead of yellow corn as energy source with alfalfa for sheep and goat. Pro. 2nd Conf. Anim. Prod. Res. Inst., Sakha: 311- 319.

Turnera, K.E., Wildeusb, S and Collinsb, J.R., (2011). Performance and nutrient utilization in purebred Spanish and Boer $\times$ Spanish and Kiko $\times$ Spanish genetic types of goats offered alfalfa hay with corn supplementation. Small Ruminant Research. 96, 144-148. 
دراسة تأثير استخدام البرسيم الحجازي في علائق الأغنام على الكفاءة الغذائية والأداء التناسلي

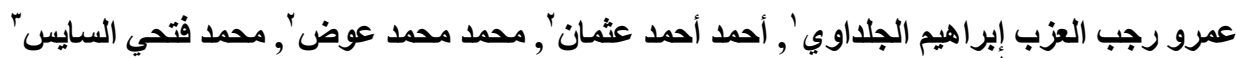

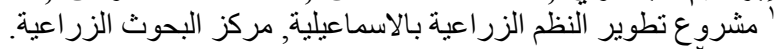

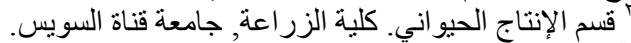

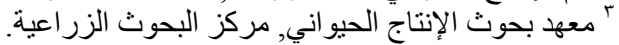

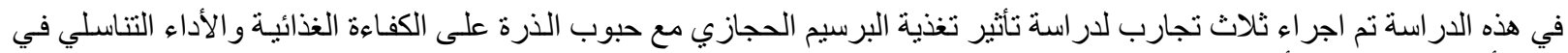

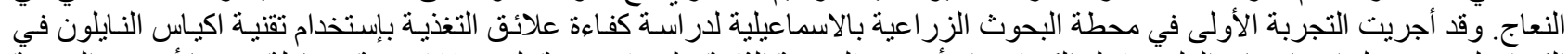

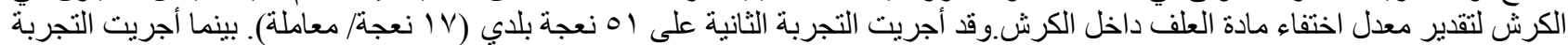

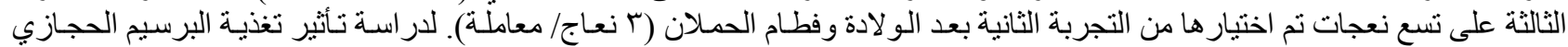

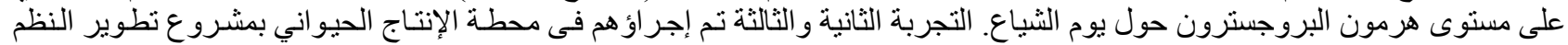

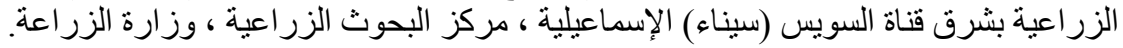

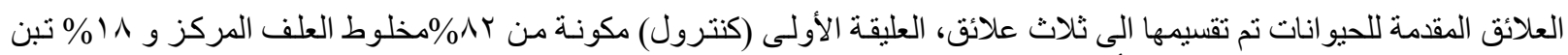

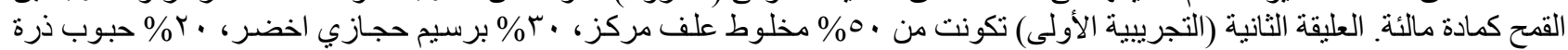

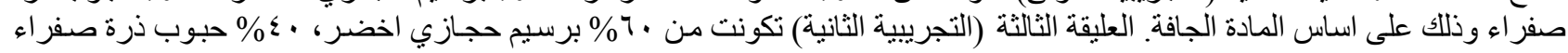
وذلك على اساس المادة الجافة خلال المر احل الفسيولوجية المختلفة للنعاج.

$$
\text { وقد اوضحت النتائج ما يلي: }
$$

ا ـ ان معدل اختفاء البروتين الخام في البرسيم الحجازي كان مرتفع معنوياً عن مخلوط العلف المركز وحبوب الذرة خاصـة عند

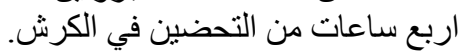

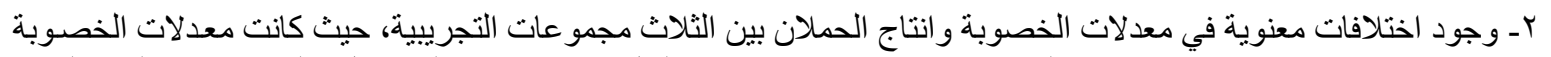

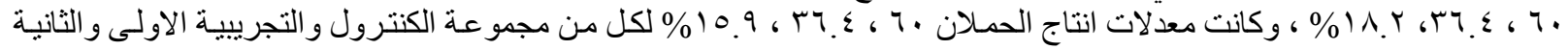
على التو الى. ولم توجد اختلافات معنوية لكل من معدلات التو التوائم و الفطام وكفاءة النعاج. بـ كانت معدلات الزيادة اليومية في نمو حملان المجمو عة التجريبية الاولى والثانية اعلى من الكنترول.

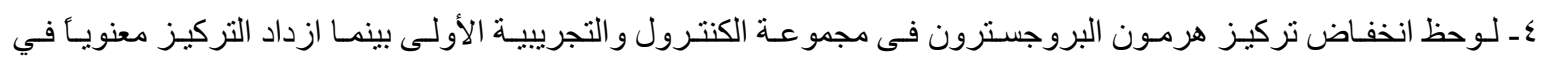

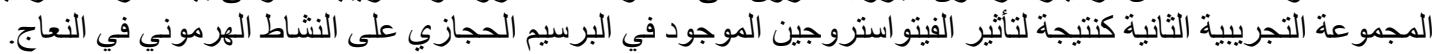
و عليه نوصي بأن لاتزيد نسبة البرسيم الحجازي في علائق الأغنام عن • ب٪\% على أسـاس المـادة الجافـة من الإحتياجـات الغذائيسة الكليـة, خاصة أثناء موسم التلقيح. 